\title{
Kelola
}

\section{KETERLAKSANAAN STANDAR PENGELOLAAN PENDIDIKAN DI SMA TERAKREDITASI}

\author{
Krisma Widi Wardani \\ Pendidikan Guru Sekolah Dasar \\ FKIP-Universitas Kristen Satya Wacana \\ krismawidi@gmail.com \\ Lobby Loekmono \\ Magister Manajemen Pendidikan \\ FKIP-Universitas Kristen Satya Wacana \\ lloekmono@yahoo.com \\ Supramono \\ Magister Manajemen Pendidikan \\ FKIP-Universitas Kristen Satya Wacana \\ supramono@staff.uksw.edu
}

\begin{abstract}
This study aims: (1) to find out the significance of differences in the implementation of the Education Management Standards in Semarang Regency Accredited Senior High School, and (2) to know the implementation of components in the Education Management Standards at Senior High School (SHS) accredited A and B in Semarang Regency which is still in the Very Low category. The type of this research is descriptive comparative with quantitative approach. The sample in this study consists of 6 Accredited $A$ and 3 Accredited B SHSs. Data or information obtained from the Principals, Vice Principals and Teachers. There are 30 respondents from 6 Accredited $A$ and 15 people from 3 Accredited B Senior High Schools. This study used a Monitoring and Evaluation of Education Management Standards questionnaire developed by BSNP 2012. The results showed that the average in Accredited A are higher from Accredited BSHSs. While from the comparative test results obtained: there is no significant difference in the implementation of education management standards between Accredited A and Accredited B Senior High Schools in Semarang Regency. The result of the categorization statistics is the result that there is no component whose implementation in the Very Low category in both Accredited A and Accredited B Senior High School. However, there are components whose implementation is still in the Moderate category of the Component Management Information System.
\end{abstract}

Keywords: Accreditation, Implementation, Accredited Senior High School, Education Management Standards. 


\section{PENDAHULUAN}

Setiap warga negara berhak memperoleh pendidikan yang bermutu. Untuk dapat menyelenggarakan pendidikan yang bermutu, setiap satuan pendidikan harus memenuhi Standar Nasional Pendidikan yang ditentukan melalui kegiatan akreditasi terhadap kelayakan setiap satuan/program pendidikan. Standar Nasional Pendidikan yang berkaitan dengan perencanaan, pelaksanaan, dan pengawasan kegiatan pendidikan pada tingkat satuan pendidikan, kabupaten/kota, provinsi, pemerintah atau nasional agar tercapai efisiensi dan efektivitas penyelenggaraan pendidikan terdapat dalam Permendiknas No. 19 Tahun 2007 tentang Standar Pengelolaan Pendidikan.

Dalam Standar Pengelolaan Pendidikan terdapat enam komponen kegiatan penting yang harus dilaksanakan oleh setiap satuan pendidikan dasar dan menengah, yaitu: 1) Perencanaan Program; 2) Pelaksanaan Rencana Kerja; 3) Pengawasan dan Evaluasi; 4) Kepemimpinan Sekolah/Madrasah; 5) Sistem Informasi Manajemen; dan 6) Penilaian Khusus. Apabila setiap jenjang pengelola satuan pendidikan berupaya memberi jaminan mutu dan dilakukan secara terstandar berkelanjutan, maka mutu pendidikan Indonesia secara nasional akan meningkat. Peningkatan mutu pendidikan akan berdampak pada mutu sumber daya manusia secara nasional. Untuk memelihara efektivitas peran para konstituen dalam pengembangan kebijakan, pengambilan keputusan, dan penyelenggaraan pendidikan diperlukan sistem tata pamong (governance). Tata pamong yang baik (good governance) jelas terlihat dari lima kriteria yaitu kredibilitas, transparansi, akuntabilitas, tanggung-jawab, dan adil (BANPT 2010:17).

Berdasarkan Instrumen Akreditasi SMA/MA dari BAS S/M (2014), tanpa mengabaikan 7 standar lainya dalam Standar
Nasional Pendidikan, secara khusus dalam penilaian Standar Pengelolaan Pendidikan ditentukan kualifikasi berdasarkan enam komponen pengukuran standar pengelolaan yang dijabarkan sebagai berikut: Sekolah/Madrasah mendapat kualifikasi A apabila: Merumuskan dan menetapkan visi, mudah dipahami dan sering disosialisaikan. Sedangkan sekolah akan mendapat kualifikasi B jika merumuskan dan menetapkan visi, mudah dipahami dan pernah di-sosialisasikan; (2) Sekolah/Madrasah mendapat kualifikasi A apabila: Sekolah/Madrasah memiliki pedoman yang mengatur tujuh atau lebih aspek pengelolaan secara tertulis. Sedangkan kualifikasi B jika memiliki pedoman yang mengatur lima atau enam aspek pengelolaan secara tertulis; (3) Sekolah/Madrasah mendapat kualifikasi A apabila: Memiliki struktur organisasi yang dipajang di dinding dan disertai uraian tugas yang jelas. Sedangkan kualifikasi B jika memiliki struktur disertai uraian tugas yang jelas; (4) Sekolah/Madrasah mendapat kualifikasi A apabila: sebanyak 76\%-100\% kegiatan sesuai dengan rencana kerja tahunan. Sedangkan kualifikasi B sebanyak 51\%-75\% kegiatan sesuai dengan rencana kerja tahunan; (5) Sekolah/Madrasah mendapat kualifikasi A apabila: melaksanakan empat atau lebih kegiatan kesiswaan. Sedangkan kualifikasi B jika melaksanakan tiga kegiatan kesiswaan; (6) Sekolah/Madrasah mendapat kualifikasi A apabila: melaksanakan empat atau lebih kegiatan pengembangan kurikulum dan pembelajaran. Sedangkan kualifikasi B jika melaksanakan tiga kegiatan pengembangan kurikulum dan pembelajaran.

Dari sebagian komponen pengukuran tersebut di atas membedakan kualifikasi sekolah berperingkat A dan B dengan sangat jelas. Meski begitu, Soedjono (2012:2) mengungkapkan faktanya penyelenggaraan akreditasi Sekolah/Madrasah saat ini menghadapi beberapa persoalan diantaranya 
(1) hasil akreditasi belum menggambarkan kondisi objektif sekolah; (2) hasil akreditasi belum menunjukkan indikator akuntabilitas; (3) hasil akreditasi sekolah belum dijadikan sebagai alat pembinaan, pengembangan dan peningkatan mutu pendidikan di sekolah; (4) peringkat hasil akreditasi belum menggambarkan kelayakan sekolah; dan (5) hasil akreditasi belum mampu memberikan rekomendasi tentang penjaminan mutu pendidikan. Menurut Asmani (2010:27) banyak pihak yang selama ini skeptis terhadap objektivitas proses dan hasil akreditasi, mereka mengukur ada banyak kejanggalan, penyalahgunaan, dan penyimpangan yang dilakukan, baik oleh pihak sekolah yang di akreditasi maupun oleh tim asesor yang berkaitan dengan korupsi, kolusi, dan nepotisme (KKN), karena assesor tidak jarang memberi kesempatan untuk mengadakan apa yang belum tersedia di lapangan.

Subagyo (2013) dalam penelitiannya mengatakan tidak ada perbedaan yang signifikan antara SD/MI Terakreditasi A dengan SD/MI Terakreditasi B dalam keterlaksanaan Standar Pengelolaan Pendidikan di Kota Salatiga. Kesimpulan dari penelitian ini kemudian dapat dijadikan landasan bahwa terdapat kesenjangan antara kondisi ideal dengan praktek. Idealnya sekolah yang terakreditasi A merupakan bukti bahwa peringkat itu menunjukkan pengelolaan pendidikan di sekolah telah memenuhi seluruh standar pengelolaan pendidikan. Hasil penelitian tentang Pengelolaan Pendidikan di SMK Farmasi "Yayasan Pharmasi" Semarang oleh Haryono (2010) menemukan bahwa SMK Farmasi Semarang belum melakukan pengelolaan pendidikan sesuai dengan Standar Pengelolaan Pendidikan secara maksimal, sekolah yang diteliti kurang memahami Standar Pengelolaan Pendidikan.

Berdasarkan hasil penelitian dan uraian di atas ditemukan bahwa pada kondisi ideal sekolah yang terakreditasi A memiliki kualifikasi lebih tinggi dari sekolah terakreditasi B. Namun dari penelitian Subagyo (2013) menunjukkan bahwa Keterlaksanaan Standar Pengelolaan Pendidikan di SD/MI Terakreditasi A dan B di Kota Salatiga tidak ada perbedaan signifikan. Begitu juga dengan penelitian Haryono (2010). Berdasarkan kontradiksi antara keadaan ideal dan hasil penelitian tersebut penulis tertarik untuk melakukan penelitian mengenai keterlaksanaan standar pengelolaan pendidikan di SMA Terakreditasi A dan B di Kabupaten Semarang.

Di Kabupaten Semarang terdapat 26 SMA Negeri dan Swasta. Bedasarkan penelitian pendahuluan diperoleh data Akreditasi SMA seperti Tabel 1 berikut ini:

Tabel 1 Daftar Akreditasi SMA Kabupaten Semarang

\begin{tabular}{cccc}
\hline \multirow{2}{*}{ Peringkat Akreditasi } & \multicolumn{2}{c}{ Jumlah Sekolah } & \multirow{2}{*}{ Jumlah Total } \\
\cline { 2 - 4 } & Negeri & Swasta & $\mathbf{1 2}$ \\
A & 8 & 4 & $\mathbf{6}$ \\
B & 0 & 6 & - \\
C & - & - & $\mathbf{3}$ \\
\hline Terakreditasi sebelum & 3 & 0 & $\mathbf{3}$ \\
2009/2010 & 0 & 3 & $\mathbf{2}$ \\
Tidak Terakreditasi & 0 & 2 & $\mathbf{2 6}$ \\
Tidak Terlacak & $\mathbf{1 1}$ & $\mathbf{1 5}$ & \\
\hline Jumlah Total & &
\end{tabular}

Sumber: Penelitian Pendahuluan, Mei 2015

Jumlah SMA yang telah terakreditasi dan yang belum terakreditasi di Kabupaten
Semarang selisihnya cukup banyak, terlebih apabila menyangkut masa berlaku akreditasi 
bagi SMA Terakreditasi A dan Terakreditasi B di Kabupaten Semarang perlu untuk dilihat keterlaksanaan standar pengelolaan pendidikan agar dapat terus menjamin keberlanjutan penjaminan mutu pendidikan. Melalui penelitian ini akan dilihat apakah ada perbedaan atau tidak mengenai keterlaksanaan standar pengelolaan di sekolah terakreditasi A dan B di Kabupaten Semarang.

Berdasarkan latar belakang masalah di atas, maka rumusan masalah dalam penelitian ini adalah: 1) Adakah perbedaan signifikan keterlaksanaan Standar Pengelolaan Pendidikan di SMA terakreditasi A dan SMA terakreditasi B di Kabupaten Semarang? 2) Komponen Standar Pengelolaan Pendidikan mana yang keterlaksanaannya masih berada dalam kategori Sangat Rendah pada SMA terakreditasi A dan B?. Sedangkan tujuan penelitian ini untuk: 1) mengetahui signifikansi perbedaan keterlaksanaan Standar Pengelolaan Pendidikan di SMA terakreditasi A dan B di Kabupaten Semarang; 2) mengetahui komponen mana dalam Standar Pengelolaan Pendidikan di SMA terakreditasi A dan B di Kabupaten Semarang yang keterlaksanaannya masih berada pada kategori Sangat Rendah.

\section{METODE PENELITIAN}

Jenis penelitian yang digunakan adalah deskriptif komparatif dengan pendekatan kuantitatif. Penelitian ini menggunakan sekolah sebagai unit analisis. Unit analisis menurut Arikunto $(2010 ; 187)$ adalah satuan tertentu yang diperhitungkan sebagai subyek penelitian. Dalam pengertian yang lain, unit analisis diartikan sebagai sesuatu yang berkaitan dengan fokus/komponen yang diteliti. Sehingga selain sekolah sebagai unit analisis juga merupakan subjek penelitian, dalam hal ini adalah SMA Terakreditasi A dan B yang berada di wilayah Kabupaten Semarang.
Populasi penelitian dalam penelitian ini adalah 12 SMA Terakreditasi A dan 6 SMA Terakreditasi B di Kabupaten Semarang. Sampel adalah sebagian dari jumlah karakteristik yang dimiliki oleh populasi. Teknik pengambilan sampel berfokus pada teknik purposive sampling. Sampel dalam penelitian ini adalah 6 SMA Terakreditasi A dan 3 SMA Terakreditasi B di Kabupaten Semarang. Data atau informasi diperoleh dari "informan (responden) penelitian" yaitu Kepala Sekolah, Wakil Kepala Sekolah dan Guru. Informan/responden dalam penelitian ini bersifat kolektif (satu kesatuan) tidak individual. Setiap sekolah diambil sebanyak 5 orang narasumber yang terdiri dari 1 kepala sekolah, 3 wakil kepala sekolah dan 1 guru.

Definisi operasional keterlaksanaan standar pengelolaan pendidikan adalah terlaksananya keseluruhan standar pengelolaan pendidikan yang mencakup perencanaan program; sistem informasi manajemen; pelaksanaan rencana kerja meliputi: Pedoman Pengelolaan, Aspek pendukung dalam penyusunan Pedoman pengelolaan dan Struktur organisasi; Kepemimpinan Sekolah; dan pengawasan dan evaluasi yang diukur melalui angket pemantauan dan evaluasi standar pengelolaan pendidikan yang dikembangkan oleh BSNP 2012.

Pengumpulan data dilakukan dengan menggunakan angket. Adapun pengisian angket keterlaksanaan standar pengelolaan pendidikan ini melibatkan 9 (sembilan) kepala sekolah dan 36 (tiga puluh enam) guru dari sembilan SMA di Kabupaten Semarang. Untuk menentukan empat guru dari setiap sekolah yang akan mengisi angket peneliti melakukan koordinasi dengan kepala sekolah untuk menunjukkan guru-guru yang mengetahui tentang akreditasi sekolah atau yang terlibat aktif dalam akreditasi sekolah sebanyak 1 (satu) guru dan 3 (tiga) guru yang lain adalah dari wakil kepala sekolah. Maka secara umum kriteria pengisi angket adalah guru yang 
paham dan berperan aktif dalam akreditasi sekolah.

Data yang terkumpul dianalisis dengan menggunakan teknik analisis statistik, yakni analisis deskriptif, uji validitas item dan uji reliabilitas instrumen penelitian, uji normalitas dan analisis perbedaan. Untuk mengetahui apakah setiap butir dalam instrumen valid atau tidak dilakukan dengan cara mengkorelasikan antara skor butir dengan skor total. Uji reliabilitas menunjukkan sejauh mana suatu hasil pengukuran relatif konsisten apabila pengukuran dilakukan terhadap aspek yang sama di waktu yang berbeda-beda. Azwar (2012:7) menyatakan bahwa suatu alat ukur pada prinsipnya dikatakan reliabel apabila mampu menunjukkan sejauh mana alat ukur tersebut dapat memberi hasil yang relatif tidak berbeda bila dilakukan pengukuran kembali terhadap subyek yang sama. Rumus Alpha
Cronbach seperti yang dikutip dari Arikunto (2010), dipakai untuk menguji reliabilitas instrumen penelitian. Penentuan kategori tingkat reliabilitas dengan koefisien Alpha Cronbach, didasarkan pada pendapat George \& Mallery (1995).

Analisis deskriptif bertujuan mendeskripsikan hasil pengukuran dari variabel keterlaksanaan standar pengelolaan pendidikan. Selanjutnya data keterlaksanaan standar pengelolaan pendidikan yang terkumpul dibagi ke dalam 5 kelas interval. Masing-masing kelas selanjutnya akan diberi kategori yaitu: Sangat Tinggi; Tinggi; Sedang; Rendah; Sangat Rendah yang berlaku pada tiap komponen. Interval untuk masing-masing komponen dalam konsep ialah: skor maksimal dikurangi skor minimal di bagi jumlah katagori sehingga diperoleh interval seperti yang terdapat pada Tabel 2 berikut ini:

Tabel 2 Perhitungan Interval masing-masing Komponen

\begin{tabular}{lcccc}
\hline \multicolumn{1}{c}{ Komponen } & Jumlah Soal & Skor Min & Skor Max & Interval \\
\hline 1. Perencanaan Program & 27 & 27 & 108 & $\mathbf{1 6}$ \\
2. Sistem Informasi Manajemen & 4 & 4 & 16 & $\mathbf{2}$ \\
3. Rencana Kerja & 27 & 27 & 108 & $\mathbf{1 6}$ \\
4. Kepemimpinan Sekolah & 20 & 20 & 80 & $\mathbf{1 2}$ \\
5. Pengawasan dan Evaluasi & 25 & 25 & 100 & $\mathbf{1 5}$ \\
\hline
\end{tabular}

Dari tabel perhitungan interval selanjutnya disusun kelas interval untuk setiap komponen. Adapun hasil kelas interval diperoleh dengan cara datum terkecil sebagai batas bawah kelas pertama, untuk menentukan batas atas kelas pertama yaitu dengan cara: menjumlahkan datum terkecil dengan panjang interval kelas kemudian dikurangi satu (1). Begitu juga dengan batas bawah kelas kedua dengan melanjutkan batas atas kelas pertama dijumlahkan dengan panjang interval kelas kemudian kurangi satu (1). Begitu seterusnya, sehingga diperoleh kelas interval sebagai berikut:

Tabel 3 Kelas Interval masing-masing komponen

\begin{tabular}{ccccccc}
\hline \multirow{2}{*}{ No. Kls } & \multirow{2}{*}{ Kategori } & \multicolumn{5}{c}{ Komponen } \\
\cline { 3 - 7 } & & $\mathbf{1}$ & $\mathbf{2}$ & $\mathbf{3}$ & $\mathbf{4}$ & $\mathbf{5}$ \\
\hline 1 & Sangat Rendah & $27-42$ & $4-6$ & $27-42$ & $20-31$ & $25-39$ \\
2 & Rendah & $43-58$ & $7-9$ & $43-58$ & $32-43$ & $40-54$ \\
3 & Sedang & $59-74$ & $10-12$ & $59-74$ & $44-55$ & $55-69$ \\
4 & Tinggi & $75-90$ & $13-14$ & $75-90$ & $56-67$ & $70-84$ \\
5 & Sangat Tinggi & $91-108$ & $15-16$ & $91-108$ & $68-80$ & $85-100$ \\
\hline
\end{tabular}


Untuk melihat apakah ada signifikansi perbedaan keterlaksanaan standar pengelolaan pendidikan SMA Terakreditasi A dan SMA Terakreditasi $\mathrm{B}$, digunakan uji beda rata-rata yang juga dikenal dengan nama t-test. Untuk mendapatkan hasil yang signifikan (mendekati kebenaran) maka digunakan derajat/tingkat keyakinan 95\% ( $\alpha=5 \%)$. Namun demikian, penulis memperhitungkan dan mempertimbangkan hasil uji $\mathrm{t}$ yang termasuk dalam derajat/tingkat keyakinan $90 \%$ atau signifikan 10\%. Sugiyono (2014) menyatakan bahwa untuk melakukan uji signifikansi komparasi data dua sampel dengan data interval atau ratio digunakan teknik statistik t-test, untuk menunjukkan bahwa dua sampel yang tidak berhubungan tersebut memiliki nilai rerata yang berbeda. Syarat atau asumsi utama yang harus dipenuhi dalam menggunakan t-test adalah data harus berdistribusi normal. Untuk menentukan apakah data yang telah dikumpulkan berdistribusi normal maka diperlukan uji normalitas. Uji normalitas dalam penelitian ini menggunakan Kolmogrov-Smirnov.

\section{HASIL PENELITIAN DAN PEMBAHASAN}

\section{Deskripsi Subyek Penelitian}

Terdapat kecenderungan bahwa SMA terakreditasi A relatif sedikit dalam pelibatan guru dibanding SMA terakreditasi B. Hal tersebut didasari dari konsultasi dengan pihak sekolah terutama wakil kepala sekolah yang lebih mengarahkan supaya responden adalah wakil kepala sekolah, sebab mereka yang terlibat aktif dalam akreditasi. Adapun rincian subyek dan narasumber penelitian terdapat pada Tabel 4 dan Tabel 5.

Tabel 4 Subyek dan Narasumber Penelitian SMA Terakreditasi A

\begin{tabular}{cllcccccccc}
\hline A. & \multicolumn{1}{c}{ Sekolah } & \multicolumn{2}{c}{ Kepala Sekolah } & \multicolumn{2}{c}{ Wakil Kepsek } & \multicolumn{2}{c}{ Guru } & Total \\
\hline \hline & \multicolumn{1}{c}{ SMA Terakreditasi A } & L & P & L & P & L & P & \\
\hline 1 & SMA Negeri 1 Ambarawa & 1 & - & 3 & - & 1 & - & 5 \\
2 & SMA Islam Sudirman Amb. & 1 & - & 1 & 2 & 1 & - & 5 \\
3 & SMA Kartika III-1 Banyubiru & 1 & - & 2 & 1 & - & 1 & 5 \\
4 & SMA Negeri 1 Suruh & 1 & - & 3 & 0 & 1 & - & 5 \\
5 & SMA Negeri 1 Bringin & - & 1 & 1 & 2 & - & 1 & 5 \\
6 & SMA Negeri 1 Tuntang & 1 & - & 1 & 2 & - & 1 & 5 \\
\hline & Jumlah & & $\mathbf{6}$ & & $\mathbf{2 1}$ & & $\mathbf{6}$ & $\mathbf{3 0}$ \\
\hline
\end{tabular}

Tabel 5 Subyek dan Narasumber Penelitian SMA Terakreditasi B

\begin{tabular}{|c|c|c|c|c|c|}
\hline B. & Sekolah & Kepala Sekolah & Wakil Kepsek & Guru & Total \\
\hline \multicolumn{6}{|c|}{ SMA Terakreditasi B } \\
\hline 1 & SMA Wira Usaha Jimbaran & 1 & 1 & 3 & 5 \\
\hline 2 & SMA Islam Sudirman Bringin & 1 & 1 & 2 & 5 \\
\hline 3 & SMA Islam Plus Bina Insani & 1 & 1 & 3 & 5 \\
\hline & Jumlah & 3 & 3 & 9 & 15 \\
\hline
\end{tabular}

Sumber data: Dokumen Sekolah yang diolah, 2015

Tabel 4 menunjukkan SMA Terakreditasi A, masing-masing sekolah ada yang memiliki empat wakil kepala sekolah dan tiga wakil kepala sekolah. Untuk sekolah dengan empat wakil kepala sekolah artinya rombongan belajar di sekolah tersebut lebih dari 27 rombongan belajar (rombel) dan untuk sekolah dengan tiga wakil kepala sekolah, artinya jumlah rombongan belajar terdiri dari 19-27 rombongan belajar. Sedangkan pada SMA terakreditasi $\mathrm{B}$ tabel 5 menunjukkan bahwa hanya terdapat satu wakil kepala sekolah, sebab dalam satu sekolah tersebut terdapat kurang dari 7 rombongan belajar, hal 
ini sesuai dengan Permendiknas No. 19 Tahun 2007.

\section{Uji Validitas}

Hasil uji validitas pada angket Keterlaksanaan Standar Pengelolaan Pendidikan dipaparkan pada Tabel 6 dengan kriteria seleksi item dilakukan berdasarkan koefisien korelasi item total terkoreksi (corrected item-total correlation). Apabila terdapat item yang memiliki skor corrected item-total correlation dibawah 0,30, maka item tersebut tidak valid sehingga tidak digunakan dalam penelitian (Sugiyono, 2014:174, Azwar, 2012:164). Berikut pada Tabel 4.2 disajikan rangkuman hasil uji validitas item.

Tabel 6 Rangkuman Hasil Uji Validitas

\begin{tabular}{|c|c|c|c|c|}
\hline $\begin{array}{c}\text { Variabel } \\
\text { Penelitian }\end{array}$ & Sub Variabel & $\begin{array}{l}\text { No. item } \\
\text { Instrumen }\end{array}$ & $\begin{array}{c}\text { Range corrected } \\
\text { item-total correlation }\end{array}$ & Validitas \\
\hline \multirow[t]{2}{*}{ Standar } & Komponen 1 & & & \\
\hline & Keterlaksanaan perencanaan program & $1-27$ & $0,349-0,811$ & $\sqrt{ }$ \\
\hline \multirow[t]{2}{*}{ Pengelolaan } & Komponen 2 & & & \\
\hline & Keterlaksanaan sistem informasi manajemen & $28-31$ & $0,713-0,855$ & $\sqrt{ }$ \\
\hline \multirow[t]{7}{*}{ Pendidikan } & Komponen 3 & $32-35$ & $0,347-0,883$ & \\
\hline & Keterlaksanaan rencana kerja (Rencana Kerja, & $36-48$ & & $\sqrt{ }$ \\
\hline & Pedoman Penge-lolaan, Aspek pendukung dalam & $69-73$ & & \\
\hline & $\begin{array}{l}\text { penyusunan Pedoman penge-loaan, Struktur } \\
\text { organisasi) }\end{array}$ & $74-78$ & & \\
\hline & $\begin{array}{l}\text { Komponen } 4 \text { Keterlaksanaan Kepemimpinan } \\
\text { Sekolah }\end{array}$ & $49-68$ & $0,474-0,817$ & $\sqrt{ }$ \\
\hline & Komponen 5 & & & \\
\hline & Keterlaksanaan pengawasan dan evaluasi, & $79-103$ & $0,507-0,843$ & $\sqrt{ }$ \\
\hline
\end{tabular}

Sumber data: Lampiran 2 yang diolah, 2015

Dari Tabel 6 di atas semua item dalam instrumen dinyatakan valid, dengan corrected item-total correlation di atas 0,30. Pada Komponen keterlaksanaan perencanaan program diketahui corrected item-total correlation terendah adalah 0,349, yang terdapat pada item nomor 25 mengenai keterlibatan Dewan Pendidik dalam penentuan Wakil Kepala Sekolah/Madrasah. Sedangkan corrected item-total correlation tertinggi adalah 0,811 pada item nomor 8 mengenai keterlibatan Komite Sekolah dalam penetapan tujuan sekolah/madrasah. Pada Komponen keterlaksanaan sistem informasi manajemen yang terdiri dari 4 item, corrected item-total correlation terendah 0,713 pada item nomor 30 mengenai Pelaporan data dan informasi sekolah/madrasah kepada dinas Kabupaten/ Kota atau Kantor Kementrian Agama Kabupaten/Kota tertinggi adalah 0,855 pada item nomor 29 mengenai Penugasan guru/tenaga kependidikan untuk penanganan sistem informasi manajemen Sekolah/ Madrasah. Komponen ketiga yaitu keterlaksanaan rencana kerja corrected itemtotal correlation terendah adalah 0,347 pada item nomor 73 mengenai Sosialisasi atau Bimbingan Teknis dari Dinas Pendidikan Kabupaten/Kota atau Kantor Kementrian Agama Kabupaten/Kota. Corrected item-total correlation tertinggi adalah 0,883 pada item nomor 37 tentang Peraturan Akademik. Pada komponen keempat yaitu keterlaksanaan Kepemimpinan Sekolah, corrected item-total correlation terendah adalah 0,474 terdapat pada item nomor 66 tentang menjalin kerja sama dengan orang tua peserta didik dan masyarakat, dan Komite Sekolah/Madrasah sedangkan corrected item-total correlation tertinggi adalah 0,817 pada item nomor 55 mengenai komunikasi untuk menciptakan dukungan intensif dari orang tua peserta didik 
dan masyarakat. Pada komponen Keterlaksanaan pengawasan dan evaluasi, corrected item-total correlation terendah adalah 0,507 pada item nomor 86 mengenai pelaporan hasil evaluasi belajar dan penilaian kepada orang tua/wali setiap akhir semester dan corrected item-total correlation tertinggi 0,843 pada item nomor 96 mengenai pelaksanaan evaluasi diri, sekolah/madrasah menyusun program penilaian kinerja untuk peningkatan kinerja sekolah. Di samping uji validitas, dilakukan pula uji reliabilitas terhadap instrument pengumpulan data sebagai berikut.
Uji Reliabilitas

Instrumen pada prinsipnya dikatakan reliabel apabila mampu menunjukkan sejauh mana alat ukur tersebut dapat memberi hasil yang relatif tidak berbeda bila dilakukan pengukuran kembali terhadap subyek yang sama. Penentuan kategori tingkat reliabilitas dengan koefisien Cronbach's Alpha, didasarkan pada pendapat George \& Mallery (1995) yang menjelaskan bahwa hasil uji reliabilitas dikategorikan Sangat Tinggi apabila Cronbach's Alpha > 0,900. Berikut pada Tabel 7 disajikan rangkuman hasil uji reliabilitas.

Tabel 7 Hasil Uji Reliabilitas Keterlaksanaan Standar Pengelolaan Pendidikan

\begin{tabular}{|c|c|c|c|c|}
\hline $\begin{array}{c}\text { Variabel } \\
\text { Penelitian } \\
\end{array}$ & Sub Variabel & $\begin{array}{c}\text { No. item } \\
\text { Instrumen }\end{array}$ & $\begin{array}{c}\text { Cronbach's } \\
\text { Alpha }\end{array}$ & Reliabellity \\
\hline \multirow{5}{*}{$\begin{array}{l}\text { Standar } \\
\text { Pengelolaan } \\
\text { Pendidikan }\end{array}$} & $\begin{array}{l}\text { Komponen } 1 \\
\text { Keterlaksanaan perencanaan program }\end{array}$ & $1-27$ & 0,939 & $\begin{array}{l}\text { Sangat } \\
\text { Tinggi }\end{array}$ \\
\hline & $\begin{array}{l}\text { Komponen } 2 \\
\text { Keterlaksanaan sistem informasi manajemen }\end{array}$ & $28-31$ & 0,843 & Tinggi \\
\hline & $\begin{array}{l}\text { Komponen } \mathbf{3} \\
\text { Keterlaksanaan rencana kerja (Rencana Kerja, } \\
\text { Pedoman Penge-lolaan, Aspek pendukung dalam } \\
\text { penyusunan Pedoman pengeloaan, Struktur } \\
\text { organisasi) }\end{array}$ & $\begin{array}{l}32-35 \\
36-48 \\
69-73 \\
74-78\end{array}$ & 0,949 & $\begin{array}{l}\text { Sangat } \\
\text { Tinggi }\end{array}$ \\
\hline & $\begin{array}{l}\text { Komponen } 4 \text { Keterlaksanaan Kepemimpinan } \\
\text { Sekolah }\end{array}$ & $49-68$ & 0,936 & $\begin{array}{l}\text { Sangat } \\
\text { Tinggi }\end{array}$ \\
\hline & $\begin{array}{l}\text { Komponen } \mathbf{5} \\
\text { Keterlaksanaan pengawasan dan evaluasi, }\end{array}$ & $79-103$ & 0,955 & $\begin{array}{l}\text { Sangat } \\
\text { Tinggi }\end{array}$ \\
\hline
\end{tabular}

Sumber data: Lampiran 3 yang diolah, 2015

Tabel 7 menunjukkan bahwa komponen sistem informasi manajemen memiliki nilai Cronbach`s Alpha 0,843 berada pada kategori Tinggi, dan pada sub variabel komponen yang lain Cronbach`s Alpha berada di atas 0,900 (kategori sangat tinggi). Hal ini menunjukkan bahwa instrumen penelitian ini reliabel.

\section{Analisis Deskriptif}

Untuk menentukan tinggi rendahnya hasil pengukuran variabel keterlaksanaan standar pengelolaan pendidikan SMA terakreditasi A maupun B digunakan 5 kategori pada tiap komponen yaitu: Sangat Tinggi; Tinggi; Sedang; Rendah; Sangat Rendah. Oleh karena semua butir item dalam angket dinyatakan valid maka tidak ada perubahan interval dari Tabel 3.

\section{Pengukuran keterlaksanaan standar pengelolaan pendidikan SMA Terakreditasi A dan B}

Adapun tinggi-rendahnya hasil pengukuran frekuensi Keterlaksanaan Perencanaan Program SMA terakreditasi A dan B dapat dikategorikan sebagai berikut: 
Tabel 8 Statistik Kategorisasi Keterlaksanaan Perencanaan Program SMA Terakreditasi A dan B

\begin{tabular}{cccccr}
\hline \multirow{2}{*}{ Kelas Interval } & \multirow{2}{*}{ Kategori } & \multicolumn{4}{c}{ Frekuensi } \\
\cline { 3 - 6 } & & \multicolumn{2}{c}{ SMA Terakreditasi A } & SMA Terakreditasi B \\
\cline { 3 - 6 } & & Jml & Persentase & Jml & Persentase \\
\hline $27-42$ & Sangat Rendah & 0 & & 0 & \\
\hline $43-58$ & Rendah & 0 & & 0 & 0 \\
\hline $59-74$ & Sedang & 0 & & 0 & $66,66 \%$ \\
\hline $75-90$ & Tinggi & IIII & $66,66 \%$ & II & II \\
\hline $91-108$ & Sangat Tinggi & II & $33,33 \%$ & I & $\mathbf{1 0 0} \%$ \\
\hline
\end{tabular}

Sumber data: Lampiran 4 yang diolah, 2015

Tabel 8 menunjukkan bahwa Keterlaksanaan Perencanaan Program pada SMA terakreditasi A di Kabupaten Semarang ada di kategori Tinggi - Sangat Tinggi. Sedangkan keterlaksanaan Perencanaan Program di SMA terakreditasi $B$ ada di kategori Tinggi - Sangat Tinggi. Hal ini sangat menarik karena SMA Terakreditasi B memiliki kecenderungan ke arah kategori Tinggi di dalam melaksanakan perencanaan program, sebanding dengan keterlaksanaan Perencanaan Program di SMA Terakreditasi A.

Tabel 9 Statistik Kategorisasi Keterlaksanaan Sistem Informasi Manajemen SMA Terakreditasi A dan B

\begin{tabular}{cccccc}
\hline \multirow{2}{*}{ Kelas Interval } & \multirow{2}{*}{ Kategori } & \multicolumn{3}{c}{ Frekuensi } \\
\cline { 3 - 5 } & & \multicolumn{2}{c}{ SMA Terakreditasi A } & \multicolumn{2}{c}{ SMA Terakreditasi B } \\
\cline { 3 - 5 } & & Jml & Persentase & Jml & Persentase \\
\hline $4-6$ & Sangat Rendah & 0 & & 0 & \\
$7-9$ & Rendah & 0 & & 0 & $100 \%$ \\
$10-12$ & Sedang & I & $16,66 \%$ & III & \\
$13-14$ & Tinggi & IIII & $66,66 \%$ & 0 & 0 \\
$14-16$ & Sangat Tinggi & I & $16,66 \%$ & $\mathbf{3}$ & $\mathbf{1 0 0 \%}$ \\
\hline
\end{tabular}

Sumber data: Lampiran 4 yang diolah, 2015

Tabel 9 menunjukkan bahwa Keterlaksanaan Sistem Informasi Manajemen pada SMA Terakreditasi A memiliki kecenderungan ke arah Sedang - Tinggi Sangat Tinggi. Sementara pada SMA Terakreditasi B cenderung pada kategori Sedang. Yang menarik dalam hal ini adalah
SMA Terakreditasi A memiliki kecenderungan kategori Sedang - Tinggi - Sangat Tinggi. Nampak bahwa keterlaksanaan Sistem Informasi Manajemen pada SMA Terakreditasi A lebih tinggi dibanding SMA Terakreditasi B.

Tabel 10 Statistik Kategorisasi Keterlaksanaan Rencana Kerja SMA Terakreditasi A dan B

\begin{tabular}{|c|c|c|c|c|c|}
\hline \multirow{3}{*}{ Kelas Interval } & \multirow{3}{*}{ Kategori } & \multicolumn{4}{|c|}{ Frekuensi } \\
\hline & & \multicolumn{2}{|c|}{ SMA Terakreditasi A } & \multicolumn{2}{|c|}{ SMA Terakreditasi B } \\
\hline & & $\mathrm{Jml}$ & Persentase & $\mathrm{Jml}$ & Persentase \\
\hline $27-42$ & Sangat Rendah & 0 & & 0 & \\
\hline $43-58$ & Rendah & 0 & & 0 & \\
\hline $59-74$ & Sedang & 0 & & 0 & \\
\hline $75-90$ & Tinggi & IIII & $66,66 \%$ & III & $100 \%$ \\
\hline
\end{tabular}




\begin{tabular}{cccccc}
$91-108$ & Sangat Tinggi & II & $33,33 \%$ & 0 & \\
\hline & Jumlah & $\mathbf{6}$ & $\mathbf{1 0 0 \%}$ & $\mathbf{3}$ & $\mathbf{1 0 0 \%}$ \\
\hline
\end{tabular}

Sumber data: Lampiran 4 yang diolah, 2015

Pada Tabel 10 menunjukkan bahwa keterlaksanaan Rencana Kerja SMA Terakreditasi A di Kabupaten Semarang masuk pada kategori Tinggi - Sangat Tinggi. Sementara Keterlaksanaan Rencana Kerja
SMA Terakreditasi B pada kategori Tinggi, Sehingga keterlaksanaan Rencana Kerja pada SMA Terakreditasi A cenderung lebih tinggi dibanding SMA Terakreditasi B.

Tabel 11 Statistik Kategorisasi Keterlaksanaan Kepemimpinan Sekolah SMA Terakreditasi A dan B

\begin{tabular}{|c|c|c|c|c|c|}
\hline \multirow{3}{*}{ Kelas Interval } & \multirow{3}{*}{ Kategori } & \multicolumn{4}{|c|}{ Frekuensi } \\
\hline & & \multicolumn{2}{|c|}{ SMA Terakreditasi A } & \multicolumn{2}{|c|}{ SMA Terakreditasi B } \\
\hline & & Jml & Persentase & Jml & Persentase \\
\hline $20-31$ & Sangat Rendah & 0 & & 0 & \\
\hline $32-43$ & Rendah & 0 & & 0 & \\
\hline $44-55$ & Sedang & 0 & & 0 & \\
\hline $56-67$ & Tinggi & IIII & $66,66 \%$ & III & $100 \%$ \\
\hline $68-80$ & Sangat Tinggi & II & $33,33 \%$ & 0 & \\
\hline \multicolumn{2}{|c|}{ Jumlah } & 6 & $100 \%$ & 3 & $100 \%$ \\
\hline
\end{tabular}

Sumber data: Lampiran 4 yang diolah, 2015

Tabel 11 menunjukkan bahwa Keterlaksanaan Kepemimpinan Sekolah pada SMA Terakreditasi A dan B memiliki kecenderungan pada kategori Tinggi - Sangat Tinggi dan pada SMA Terakreditasi B pada katagori Tinggi. Nampak Bahwa keterlaksanaan Kepemimpinan Kepala Sekolah pada SMA Terakreditasi A lebih tinggi dibanding SMA Terakreditasi B.

Tabel 12 Statistik Kategorisasi Keterlaksanaan Pengawasan dan Evaluasi SMA Terakreditasi A dan B

\begin{tabular}{cccccc}
\hline \multirow{2}{*}{ Kelas Interval } & \multirow{2}{*}{ Kategori } & \multicolumn{4}{c}{ Frekuensi } \\
\cline { 3 - 5 } & & SMA Terakreditasi A & SMA Terakreditasi B \\
\cline { 3 - 5 } & & Jml & Persentase & Jml & Persentase \\
\hline $25-39$ & Sangat Rendah & 0 & 0 & \\
$40-54$ & Rendah & 0 & & 0 & \\
$55-69$ & Sedang & 0 & & 0 & $100 \%$ \\
$70-84$ & Tinggi & IIIII & $83,33 \%$ & III & \\
$85-100$ & Sangat Tinggi & I & $16,66 \%$ & 0 & $\mathbf{3}$ \\
\hline
\end{tabular}

Sumber data: Lampiran 4 yang diolah, 2015

Tabel 12 menunjukkan Keterlaksanaan Pengawasan dan Evaluasi pada SMA terakreditasi A dan B sama-sama memiliki kecenderungan pada kategori Tinggi. Hal ini sangat menarik karena SMA Terakreditasi A dan B dalam Keterlaksanaan Pengawasan dan evaluasi diri menilai Tinggi.

\section{Analisis Perbedaan}

Uji normalitas terhadap variabel keterlaksanaan standar pengelolaan pendidikan di SMA Terakreditasi A dan SMA Terakreditasi B dalam penelitian ini tampak pada Tabel 13 di bawah ini. 
Tabel 13. Tests of Normality

\begin{tabular}{|c|c|c|c|c|c|c|c|}
\hline & \multirow{2}{*}{ Sekolah } & \multicolumn{3}{|c|}{ Kolmogorov-Smirnov ${ }^{\mathrm{a}}$} & \multicolumn{3}{|c|}{ Shapiro-Wilk } \\
\hline & & Statistic & df & Sig. & Statistic & df & Sig. \\
\hline \multirow[t]{2}{*}{ Skor } & Akreditasi A & .269 & 6 & .200 & .930 & 6 & .582 \\
\hline & Akreditasi B & .280 & 3 & . & .938 & 3 & .520 \\
\hline
\end{tabular}

a. Lilliefors Significance Correction

Tabel 13 menunjukkan bahwa hasil uji normalitas SMA Terakreditasi A mempunyai tingkat probabilitas sebesar 0,582 >0,05 dan SMA Terakreditasi B mempunyai tingkat probabilitas sebesar $0,520>0,05$. Hal ini bermakna bahwa data rata-rata skor angket keterlaksanaan standar pengelolaan pendidikan SMA Terakreditasi A dan B Kabupaten Semarang mempunyai distribusi normal.
Untuk mengetahui ada atau tidaknya signifikansi perbedaan keterlaksanaan standar pengelolaan pendidikan antara SMA Terakreditasi A dengan SMA Terakreditasi B, dilakukan dengan menggunakan analisis statistik Uji-T. Hasil Uji-T yang telah dilakukan dapat dilihat pada Tabel 14 berikut ini.

Tabel 14 Hasil Analisis Keterlaksanaan Standar Pengelolaan Pendidikan antara SMA Terakreditasi A dengan SMA Terakreditasi B

Panel A. Deskriptif

\begin{tabular}{|c|c|c|c|c|c|}
\hline Akreditasi Sekolah & $\mathrm{N}$ & Mean & \multicolumn{2}{|c|}{ Std. Deviation } & Std. Error Mean \\
\hline AKreditasi A & 6 & 683.83 & \multicolumn{2}{|c|}{49.418} & 20.175 \\
\hline Akreditasi B & 3 & 661.67 & \multicolumn{2}{|c|}{18.583} & 10.729 \\
\hline \multicolumn{6}{|c|}{ Panel B. Uji Statistik Perbedaan (T-Test) } \\
\hline & \multicolumn{2}{|c|}{$\begin{array}{c}\text { Levene's Test for Equality of } \\
\text { Variances }\end{array}$} & \multicolumn{3}{|c|}{ t-test for Equality of Means } \\
\hline & $\mathrm{F}$ & Sig. & $\mathrm{t}$ & df & Sig. (2-tailed) \\
\hline Equal variances assumed & 2.459 & .161 & .730 & 7 & .489 \\
\hline Equal variances not assumed & & & .970 & 6.857 & .365 \\
\hline
\end{tabular}

Sumber data: Lampiran 5, 2016

Tabel 14 bagian Independent Samples Test, kolom Levene's test adalah untuk uji homogenitas (perbedaan varians). Pada tabel tampak bahwa $\mathrm{F}=2.459(\mathrm{p}=0,161)$ karena $\mathrm{p}$ diatas 0,05 maka dapat dikatakan bahwa tidak ada perbedaan varians pada data keterlaksanaan standar pengelolaan pendidikan atau dapat disimpulkan bahwa data hasil penelitian ini adalah homogen maka selanjutnya yang dibaca adalah equal variance assumed. Terlihat bahwa nilai t hitung $=0.730$ dan probabilitas 0,489 ( $\mathrm{sig}<0,05$ ), artinya tidak ada perbedaan keterlaksanaan standar pengelolaan pendidikan antara SMA terakreditasi A dan SMA Terakreditasi B.
Dengan demikian ini bermakna bahwa tidak ada perbedaan signifikan dalam keterlaksanaan standar pengelolaan pendidikan antara SMA terakreditasi A dengan SMA Terakreditasi B.

Selanjutnya Panel A menunjukkan bahwa keterlaksanaan standar pengelolaan pendidikan SMA Terakreditasi A lebih tinggi dibanding SMA Terakreditasi B (683,83 > 661,67). Meskipun tidak ada perbedaan signifikan, namun dapat dikatakan bahwa SMA Terakreditasi A memiliki rerata (mean) lebih tinggi,walau dari uji-t terlihat bahwa tidak ada perbedaan yang signifikan. Hal ini dikarenakan selisih skor di antara kedua kelompok SMA itu tipis. 
Analisis Perkomponen

Pada Tabel 15 Panel A menunjukkan bahwa Skor rerata (mean) keterlaksanaan
Perencanaan Program (item 1-27) SMA Terakreditasi A lebih tinggi dibanding SMA Terakreditasi B $(88,16>87,66)$ dengan selisih yang tipis.

Tabel 15 Hasil Analisis Komponen Perencanaan Program

Panel A. Deskriptif

\begin{tabular}{|c|c|c|c|c|c|}
\hline Sekolah & $\mathrm{N}$ & Mean & Std. Deviation & \multicolumn{2}{|c|}{ Std. Error Mean } \\
\hline AKreditasi A & 6 & 88.1667 & 6.79461 & \multicolumn{2}{|r|}{2.77389} \\
\hline Akreditasi B & 3 & 87.6667 & 3.05505 & \multicolumn{2}{|r|}{1.76383} \\
\hline \multicolumn{6}{|c|}{ Panel B. Uji Statistik Perbedaan (T-Test) } \\
\hline & \multicolumn{2}{|c|}{$\begin{array}{c}\text { Levene's Test for Equality of } \\
\text { Variances }\end{array}$} & \multicolumn{3}{|c|}{ t-test for Equality of Means } \\
\hline & $\mathrm{F}$ & Sig. & $\mathrm{T}$ & Df & Sig. (2-tailed) \\
\hline Equal variances assumed & 1.773 & .225 & .118 & 7 & .909 \\
\hline Equal variances not assumed & & & .152 & 7.000 & .883 \\
\hline
\end{tabular}

Hasil uji-t pada komponen Perencanaan Program menunjukkan t hitung $=$ 0,118 dengan probabilitas 0,909 > 0,05 maka dapat disimpulkan tidak ada perbedaan yang signifikan pada komponen Perencanaan Program dalam Standar Pengelolaan Pendidikan antara SMA Terakreditasi A dan SMA Terakreditasi B.

$$
\text { Dalam keterlaksanaan Sistem }
$$

Informasi Manajemen antara SMA Terakreditasi A dan SMA Terakreditasi B (item 28-31) menunjukkan bahwa ada perbedaaan rerata dimana SMA Terakreditasi A lebih tinggi dari SMA Terakreditasi B $(13,16>11,00)$. Hal ini menunjukkan bahwa ada selisih rerata SMA Terakreditasi A dan B di Kabupaten Semarang dalam melaksanakan Sistem Informasi Manajemen. Meskipun memliki selisih yang tipis kedua rerata tersebut berada pada kategori yang berbeda (SMA Terakreditasi B Sedang dan SMA Terakreditasi A Tinggi). Hal ini diperkuat dengan hasil uji-t seperti pada Tabel 16 berikut ini.

Tabel 16 Hasil Analisis Komponen Sistem Informasi Manajemen

Panel A. Deskriptif

\begin{tabular}{|c|c|c|c|c|c|}
\hline Sekolah & $\mathrm{N}$ & Mean & Std. Deviation & \multicolumn{2}{|c|}{ Std. Error Mean } \\
\hline AKreditasi A & 6 & 13.1667 & 1.32916 & & .54263 \\
\hline Akreditasi B & 3 & 11.0000 & 1.00000 & & .57735 \\
\hline \multicolumn{6}{|c|}{ Panel B. Uji Statistik Perbedaan (T-Test) } \\
\hline & \multicolumn{2}{|c|}{$\begin{array}{c}\text { Levene's Test for Equality of } \\
\text { Variances }\end{array}$} & \multicolumn{3}{|c|}{ t-test for Equality of Means } \\
\hline & $\mathrm{F}$ & Sig. & $\mathrm{t}$ & Df & Sig. (2-tailed) \\
\hline Equal variances assumed & .145 & .714 & 2.463 & 7 & .043 \\
\hline Equal variances not assumed & & & 2.735 & 5.406 & .038 \\
\hline
\end{tabular}


Tabel 16 Panel B menunjukkan hasil uji-t pada komponen Sistem Informasi Manajemen $\mathrm{t}$ hitung $=2.463$ dan $\mathrm{p}=0,043$ (sig $<0,05)$ artinya ada perbedaan yang signifikan pada komponen Sistem Informasi Manajemen dalam Standar Pengelolaan Pendidikan antara SMA Terakreditasi A dan SMA Terakreditasi B.

Dalam komponen Pelaksanaan Rencana Kerja (item 32-48; 69-78) SMA
Terakreditasi A memiliki rerata lebih tinggi dibanding SMA terakreditasi B (89,33 > 85,00) seperti Pada Tabel 16 Panel A, selisih keduanya tipis dan berada pada kategori yang sama yaitu Tinggi. Hal ini menunjukkan bahwa SMA terakreditasi A dan B di dalam melaksanakan Rencana Kerja sama-sama memiliki kecenderungan ke arah kategori Tinggi.

Tabel 17 Hasil Analisis Komponen Pelaksanaan Rencana Kerja

Panel A. Deskriptif

\begin{tabular}{|c|c|c|c|c|c|}
\hline Sekolah & $\mathrm{N}$ & Mean & Std. Deviation & \multicolumn{2}{|c|}{ Std. Error Mean } \\
\hline AKreditasi A & 6 & 89.3333 & 5.88784 & & 2.40370 \\
\hline Akreditasi B & 3 & 85.0000 & 1.73205 & & 1.00000 \\
\hline \multicolumn{6}{|c|}{ Panel B. Uji Statistik Perbedaan (T-Test) } \\
\hline & \multicolumn{2}{|c|}{$\begin{array}{c}\text { Levene's Test for Equality of } \\
\text { Variances }\end{array}$} & \multicolumn{3}{|c|}{ t-test for Equality of Means } \\
\hline & $\mathrm{F}$ & Sig. & $\mathrm{t}$ & & Sig. (2-tailed) \\
\hline Equal variances assumed & 2.442 & .162 & 1.211 & 7 & .265 \\
\hline Equal variances not assumed & & & 1.664 & 6.401 & .144 \\
\hline
\end{tabular}

Hasil uji-t seperti tampak pada Tabel 17. $\mathrm{t}$ hitung $=1.211$ dan $\mathrm{p}=0,265(\mathrm{sig}>0,05)$ artinya tidak ada perbedaan yang signifikan pada komponen Pelaksanaan Rencana Kerja dalam Standar Pengelolaan Pendidikan antara SMA Terakreditasi A dan SMA Terakreditasi B.
Dalam keterlaksanaan Kepemimpinan Sekolah (item 49-68) SMA Terakreditasi A memiliki rerata lebih tinggi dari SMA Terakreditasi B $(66,16>64,66)$ meskipun memiliki selisih tipis dan keduanya berada pada kategori Tinggi.

Tabel 18 Hasil Analisis Komponen Kepemimpinan Sekolah

Panel A. Deskriptif

\begin{tabular}{|c|c|c|c|c|c|}
\hline Sekolah & $\mathrm{N}$ & Mean & Std. Deviation & \multicolumn{2}{|c|}{ Std. Error Mean } \\
\hline AKreditasi A & 6 & 66.1667 & 5.56477 & & 2.27181 \\
\hline Akreditasi B & 3 & 64.6667 & 2.51661 & & 1.45297 \\
\hline \multicolumn{6}{|c|}{ Panel B. Uji Statistik Perbedaan (T-Test) } \\
\hline & \multicolumn{2}{|c|}{$\begin{array}{c}\text { Levene's Test for Equality of } \\
\text { Variances }\end{array}$} & \multicolumn{3}{|c|}{ t-test for Equality of Means } \\
\hline & $\mathrm{F}$ & Sig. & $\mathrm{t}$ & $f$ & Sig. (2-tailed) \\
\hline Equal variances assumed & 1.638 & .241 & .434 & 7 & .678 \\
\hline Equal variances not assumed & & & .556 & 6.999 & .595 \\
\hline
\end{tabular}

Berdasarkan Tabel 18 tampak bahwa $\mathrm{t}$ hitung $=0,434$ dengan probabilitas $0,678>$ 0,05 . Hal ini bermakna tidak ada perbedaan signifikan pada komponen Kepemimpinan Sekolah dalam Standar Pengelolaan 
Pendidikan antara SMA Terakreditasi A dengan SMA Terakreditasi B.

Dalam keterlaksanaan Pengawasan dan Evaluasi (item 79-103) terlihat bahwa rerata
SMA Terakreditasi A lebih tinggi dari SMA terakreditasi B $(78,66>77,66)$ dengan selisih tipis dan berada pada kategori yang sama yaitu kategori Tinggi.

Tabel 19 Hasil Analisis Komponen Pengawasan dan Evaluasi

Panel A. Deskriptif

\begin{tabular}{|c|c|c|c|c|c|}
\hline Sekolah & $\mathrm{N}$ & Mean & Std. Deviation & \multicolumn{2}{|c|}{ Std. Error Mean } \\
\hline AKreditasi A & 6 & 78.6667 & 7.47440 & \multicolumn{2}{|r|}{3.05141} \\
\hline Akreditasi B & 3 & 77.6667 & 1.52753 & & .88192 \\
\hline \multicolumn{6}{|c|}{ Panel B. Uji Statistik Perbedaan (T-Test) } \\
\hline & \multicolumn{2}{|c|}{$\begin{array}{c}\text { Levene's Test for Equality of } \\
\text { Variances }\end{array}$} & \multicolumn{3}{|c|}{ t-test for Equality of Means } \\
\hline & $\mathrm{F}$ & Sig. & $\mathrm{T}$ & \multicolumn{2}{|r|}{ Sig. (2-tailed) } \\
\hline Equal variances assumed & 4.425 & .073 & .222 & 7 & .831 \\
\hline Equal variances not assumed & & & .315 & 5.770 & .764 \\
\hline
\end{tabular}

Berdasarkan Tabel 19 terlihat bahwa t hitung $=0,222$ dengan $\mathrm{p}=0,831>0,05$, hal ini bermakna tidak ada perbedaan signifikan pada komponen Pengawasan dan Evaluasi dalam Standar Pengelolaan Pendidikan antara SMA Terakreditasi A dan SMA Terakreditasi B. Sehingga dapat disimpulkan meski SMA Terakreditasi A lebih tinggi keterlaksanaannya, tapi dari uji-t terlihat bahwa tidak ada perbedaan yang signifikan. Hal ini karena selisihnya sangat tipis.

\section{Pembahasan Hasil Penelitian}

Dari hasil analisis komparatif yang dilakukan, terlihat tidak ada perbedaan signifikan antara SMA Terakreditasi A dengan SMA Terakreditasi B dalam Keterlaksanaan Standar Pengelolaan Pendidikan. Meskipun tidak ada perbedaan signifikan, namun dapat dikatakan bahwa SMA Terakreditasi A memiliki rerata (mean) lebih tinggi meskipun selisihnya hanya tipis.

Dalam hal ini, SMA Terakreditasi B dalam evaluasi diri dapat dikatakan menilai tinggi sedangkan assesor tidak, sehingga berfikir terakreditasi A. Sedangkan tuntutan untuk Terakreditasi A lebih tinggi dari Terakreditasi B. Dari hasil informasi mengenai keterlaksanaan Standar Pengelolaan Pendidikan di sekolah, Peneliti percaya dengan hasil angket penilaian yang diberikan oleh pihak sekolah (responden), sehingga tidak kembali mempertanyakan keberadaan bukti fisik. Sementara dalam wawancara singkat dengan beberapa Responden, kecenderungan yang ditemui adalah keterangan jawaban memang berpatokan pada keberadaan alat bukti fisik sehingga responden memberi penilaian tinggi, namun tidak berlanjut pada keterukuran apakah yang tertulis telah terlaksana sesuai pada substansi tujuan atau belum. Dapat dikatakan bahwa responden memiliki kecenderung memberi nilai tinggi pada setiap poin, namun belum ada keterukuran yang sama antar responden pada satu sekolah hal ini terjadi karena adanya pemahaman yang berbeda-beda antar pelaksana program. Misalnya pada visi, misi, tujuan, KTSP, Pembagian tugas kependidikan, kode etik sekolah, pembinaan prestasi unggulan, layanan bimbingan konseling, pelacakan lulusan, peningkatan mutu pendidikan, kepala laboratorium, evaluasi dan pengembangan KTSP semua telah ada namun tidak benar-benar menjadi acuan dalam menjalankan dan tidak dilengkapi dengan 
metode pelaksanaan yang terukur hanya sebatas sosialisasi.

Sedangkan untuk SMA Terakreditasi A, dalam evaluasi diri menilai dengan hati-hati sehingga nampak seperti "pelit nilai" atau dapat dikatakan faking bad terhadap sekolahnya sendiri sehingga ini berakibat pada hasil. Secara kasar tidak ada perbedaan signifikan antara SMA Terakreditasi A dengan SMA Terakreditasi B. Pada Sekolah yang terakreditasi A tuntutan yang harus dipenuhi dalam penilaian tentu lebih tinggi dari sekolah yang terakreditasi B. Sekolah Terakreditasi A memliki program unggulan atau spesifikasi.

Ketika tidak ada perbedaan signifikan pada Keterlaksanaan Standar Pengelolaan Pendidikan maka dibuatlah analisis komponen.

Hasil dari analisis komponen diketahui bahwa pada Komponen Sistem Informasi Manajemen terdapat perbedaan signifikan antara SMA Terakreditasi A dan SMA Terakreditasi B. Pada Komponen Sistem Informasi Manajemen diketahui pada analisis deskriptif menunjukkan bahwa terdapat selisih rerata (kolom mean dan Katagori) dan meskipun memiliki selisih tipis namun keduanya berada pada kategori yang berbeda. Hal ini terjadi karena di SMA Terakreditasi A dalam Keterlaksanaan Sistem Informasi Manajemen telah tersedia fasilitas sistem informasi manajemen sekolah yang memadai, ada penugasan guru dan bahkan tenaga kependidikan untuk penanganan sistem informasi manajemen sekolah sehingga pelaporan data dan informasi sekolah kepada dinas Kabupaten atau kantor kementrian lebih tertangani tepat waktu, keberadaannyapun dapat dipahami oleh warga sekolah. Sedangkan pada SMA Terakreditasi B ketersediaan Fasilitas sistem Infromasi Manajemen masih terbatas jumlahnya dan tidak dapat memenuhi ratio siswa, sehingga dalam pemanfaatannyapun dibatasi hanya untuk Guru terutama penggunaan media komputer dan internet sekolah. Hal tersebut selanjutnya juga berimbas pada pelaporan data dan informasi sekolah ke dinas Kabaupaten dan Kantor Kementrian Agama yang lebih sering dituntut dilakukan secara online akan tetapi karena akses internet terbatas sehingga itu terkadang menjadi kendala. Keberadaan Sistem Informasi Manajemen Sekolah dapat di pahami oleh warga sekolah, meskipun fasilitas terbatas melalui papan pengumuman.

Sedangkan hasil analisis 4 komponen lainnya yaitu keterlaksanaan Perencanaan Program; Keterlaksanaan Rencana Kerja; Kepemimpinan Sekolah; dan yang terakhir Pengawasan dan Evaluasi tidak ada perbedaan signifikan. Hal ini terjadi karena di SMA Terakreditasi A dalam memberikan penilaian pada keterlaksanaannya tidak jauh berbeda dengan SMA Terakreditasi B. Hal ini nampak pada analisis deskriptif, yang menunjukkan rerata (mean) memiliki selisih yang tipis dan berada pada kategori yang sama.

\section{SIMPULAN DAN SARAN}

\section{Simpulan}

Berdasarkan hasil penelitian yang telah dilakukan berkenaan dengan keterlaksanaan Standar Pengelolaan Pendidikan SMA Terakreditasi A dan SMA Terakreditasi B di Kabupaten Semarang, dengan merujuk pada rumusan masalah simpulan penelitian ini adalah:

1. Tidak ada Perbedaan Signifikan Keterlaksanaan Standar Pengelolaan Pendidikan SMA Terakreditasi A dan SMA Terakreditasi B di Kabupaten Semarang.

2. Bahwa tidak ada Komponen yang keterlaksanaannya berada pada kategori Sangat Rendah baik di SMA Terakreditasi A maupun SMA Terakreditasi B. Namun demikian ada komponen yang keterlaksanaannya masih berada pada kategori Sedang yaitu Komponen Sistem Informasi Manajemen. Hal ini disimpulkan dari hasil analisis deskriptif dalam statistik 
kategorisasi keterlaksanaan Sistem Informasi Manajemen.

\section{Saran}

Saran untuk peneliti selanjutnya perlu mengembangkan pengayaan instrumen Standar Pengelolaan Pendidikan serta mengukur Keterlaksanaan Standar Pengelolaan Pendidikan dari perspektif penerima manfaat (Murid, orang tua, masyarakat dan dunia usaha) karena penelitian ini belum mencakup pada bagian itu.

\section{DAFTAR PUSTAKA}

Arikunto, 2010. Prosedur Penelitian: Suatu Pendekatan Praktik. (Edisi Revisi). Jakarta: Rineka Cipta.

Asmani, J. M. 2010. Tips Lulus Akreditasi Sekolah/-Madrasah Panduan

Manajemen Mutu Sekolah/-Madrasah Berorientasi Kompetitif, Yogyakarta: Laksana.

Azwar, S. 2012. Reliabilitas dan Validitas edisi IV, Yogyakarta: Pustaka Pelajar.

BAN PT. 2010. Akreditasi Program Studi Magister Buku I Naskah Akademik BAN PT 2009, Jakarta: Badan Akreditasi Nasional Perguruan Tinggi

Badan Akreditasi Nasional Sekolah/Madrasah. 2014. Instrumen Akreditasi SMA/MA. Jakarta: BAN S/M diakses pada: 12 Maret 2015

BSNP, 2012. Instrumen Evaluasi Diri Sekolah, Jakarta: Badan Standar Nasional Pendidikan.

\section{Naskah Akademik Standar}

Pengelolaan Pendidikan Dasar dan Menengah, Jakarta: Badan Standar Nasional Pendidikan.
George, D \& Mallery, P., 1995. SPSS/PC + by step $\alpha$ simple Guide and Reference. Belmont: Wadsworth Pub.Co.

Haryono, 2010. "Analisis Perbandingan Sistem Penge-lolaan Pendidikan di SMK Farmasi Semarang”, Tesis, Salatiga: MMP Universitas Kristen Satya Wacana.

Jumlah Sekolah, Murid dan Guru SMA http://semarangkab.bps.go.id/ diakses pada 10 Januari 2015 Pukul 20.00

Peraturan Menteri Pendidikan Nasional Republik Indonesia Nomor 19 Tahun 2007 Tentang Standar Pengelolaan Pendidikan Oleh Satuan Pendidikan dasar dan Menengah.

Subagyo, W. 2013. "Perbedaan keterlaksanaan Standar Pengelolaan Pendidikan antara SD/MI terakreditasi A dengan B di Kota Salatiga”, Tesis, Salatiga: MMP Universitas Kristen Satya Wacana.

Sugiyono, 2014. Metode Penelitian Kombinasi (Mixed Method), Bandung: Alfabeta. 